\title{
POTENSI PENGEMBANGAN DAYA TARIK WISATA DI DESTINASI PARIWISATA IKAN SAKTI SUNGAI JANIAH KECAMATAN BASO KABUPATEN AGAM SUMATERA BARAT
}

\author{
Hendri Azwar' ${ }^{1,}$ Himawan Brahmantyo ${ }^{2}$. \\ ${ }^{1,2,}$ Trisakti School of Tourism \\ Email: hendriazwar5@gmail.com
}

\begin{abstract}
This study aims to analyze the potential development of a tourist attraction in Tourism Destinations of Ikan Sakti Sungai Janiah Kecamatan Baso Kabupaten Agam. This study used qualitative and SWOT analysis. The data source is Head of Tourism, Youth and Sports, the Chief Manager of Tourism Destinations, Community Leaders, and tourists. The techniques of data collection were through interviews, observation, and documentation. Data were analyzed qualitatively including reduction, data presentation, and conclusions. The results showed that the potential development of tourist attraction in this tourists destination is tracking, flying fox, fishing pond, bathhouse, camping area, playground, park, packaging art such as; Randai, dances, Debus, Talempong Pacik, Pupuik, Makan Bajamba, and Martial Arts Performances. Development strategies of a tourist attraction by optimizing the natural resources that already exist, giving training in tourism awareness to the community, building cooperation with local governments, managers and the public in the packaging of a tourist attraction, improve human resources by providing training and looking for investors in the development of tourist attraction, and increasing community involvement in the management of a tourist attraction.
\end{abstract}

\section{Keywords: Potensi, Pengembangan, Daya Tarik, Destinasi}

\section{PENDAHULUAN}

Destinasi Pariwisata Ikan Sakti Sungai Janiah merupakan salah satu destinasi di Kecamatan Baso Kabupaten Agam yang akan dikembangkan oleh pemerintah. Ini terlihat dalam rencana induk pembangunan kepariwisataan Kabupaten Agam 2016 yang menjadikan destinasi ini sebagai Destinasi Utama Kabupaten Agam ke Empat (DUPK4). Secara geografis destinasi pariwisata ini berada diantara $0^{\circ}$ - 3o LS, $100.28^{\circ} \mathrm{BT}$, dengan luas 19,19 KM2 berada pada ketinggian $800-900 \mathrm{~m}$ dpl.

Daya tarik yang dimiliki oleh destinasi pariwisata ini seperti alam yang indah, flora dan fauna serta udara yang masih terjaga. Kemudian daya tarik budaya yang memiliki keunikan tersendiri seperti adat istiadat serta kehidupan dalam masyarakat. Selanjutnya daya tarik buatan yang ada berupa bangunan peninggalan secara turun temurun berupa rumah gadang (rumah adat) yang masih dijaga sampai saat ini. Dengan adanya daya tarik tersebut, jika di kembangkan dapat meningkatkan kunjungan wisatawan ke Destinasi Pariwisata Ikan Sakti Sungai Janiah.

Namun pada saat ini tingkat kunjungan wisatawan ke destinasi pariwisata tersebut masih kurang stabil. Ini terlihat masih sedikitnya wisatawan yang berkunjung serta daya tarik yang dimiliki masih kurang dikenal oleh wisatawan. Sedangkan daya tarik wisata sangat menunjang 
kelangsungan dan pertumbuhan kepariwisataan daerah secara kompetitif serta mampu memiliki daya saing dan nilai lebih dari destinasi pariwisata lainnya. Oleh karena itu, penelitian ini bertujuan untuk menganalisis Potensi Pengembangan Daya Tarik Wisata di Destinasi Pariwisata Ikan Sakti Sungai Janiah Kecamatan Baso Kabupaten Agam Sumatera Barat

\section{LANDASAN TEORI}

1. Pariwisata Pariwisata merupakan aktivitas, pelayanan, dan produk hasil industri pariwisata yang dapat menciptakan pengalaman baru bagi wisatawan. Menurut Undang-Undang No.10 Tahun 2009 tentang kepariwisataan,

"Pariwisata adalah berbagai macam kegiatan wisata dan didukung berbagai fasilitas serta layanan yang disediakan oleh masyarakat, pengusaha, pemerintah, dan pemerintah daerah".

\section{Destinasi Pariwisata}

Menurut UU No. 10 Tahun 2009 tentang kepariwisataan, "Destinasi pariwisata atau daerah tujuan pariwisata adalah kawasan geografis yang berada dalam satu atau lebih wilayah administratif yang didalamnya terdapat daya tarik wisata, fasilitas umun, fasilitas pariwisata, aksesibilitas, serta masyarakat yang saling terkait dan melengkapi terwujudnya kepariwisataan.

Berbeda dengan yang dikemukakan oleh Kelly dan Narkervis (2001),

"Effective coordination of a destinations tourism operations depends upon a clear understanding of the resources available, the extent to which tourism development has ready occurred, and the interrelationship among these development"

\section{Daya Tarik Wisata}

Daya Tarik Wisata adalah segala sesuatu yang memiliki keunikan, keindahan, dan nilai yang berupa keanekaragaman kekayaan alam, budaya, dan hasil buatan manusia yang menjadi sasaran atau tujuan kunjungan wisatawan (Undang-Undang No.10 Tahun 2009). Suchaina (2014) mengemukakan tiga klasifikasi daya tarik wisata yaitu: “(a) daya tarik wisata alamiah (natural attractions), (b) daya tarik wisata budaya (cultural attractions), (c) daya tarik wisata buatan/binaan manusia (man made attractions)".

\section{METODOLOGI PENELITIAN}

Penelitian tentang

Potensi

Pengembangan Daya Tarik Wisata di Destinasi Pariwisata Ikan Sakti Sungai Janiah Kecamatan Baso Kabupaten Agam Sumatera Barat menggunakan metode kualitatif dan analisis SWOT. Menurut Sugiyono (2011:306)

"Peneliti kualitatif sebagai human instruments, berfungsi menetapkan fokus masalah, memilih informan sebagai sumber data, melakukan pengumpulan data, menilai kualitas data, analisis data, menafsirkan data dan membuat kesimpulan atas temuannya".

Penelitian ini dilakukan dengan cara observasi, wawancara, dan dokumentasi. Sumber data dalam penelitian ini adalah Kepala Dinas Pariwisata Pemuda Dan Olahraga Kabupaten 
Agam, Ketua Pengelola Destinasi Pariwista Ikan Sakti Sungai Janiah, Tokoh Masyarakat yang direkomendasi oleh Ketua Pengelola Destinasi Pariwista Ikan Sakti Sungai Janiah dan wisatawan.

\section{GAMBARAN OBJEK PENELITIAN}

Sungai Janiah merupakan salah satu Jorong (Desa) yang dikelilingi oleh hamparan bukit barisan (Bukit terpanjang di Pulau Sumatera) yang terdapat di Kecamatan Baso Kabupaten Agam yang secara geografis berada diantara $0^{\circ}-3 \mathrm{oLS}, 100.28^{\circ} \mathrm{BT}$, dengan luas \pm 4,2 Km2 berada pada ketinggian 800 - 900 mdpl. Desa ini memiliki keunikan dan keindahan tersendiri seperti alam yang masih asri dan hutan masih terjaga, budaya masyarakat yang menjunjung tinggi adat istiadat dengan dan penduduknya.

Destinasi Pariwisata Ikan Sakti Sungai Janiah sudah lama dikelola oleh masyarakat sekitar, namun pada akhir tahun 2016 baru melakukan kerjasama dengan Dinas Pariwisata Pemuda dan Olahraga. Pengelolaan operasional secara lansung dilakukan oleh masyarakat, sedangkan Pemerintah hanya sebagai pembina dan mendorong terhadap pengembangan destinasi pariwisata tersebut.

\section{HASIL PENELITIAN}

1. Daya Tarik Alam

Destinasi Pariwisata Ikan Sakti Sungai Janiah memiliki beberapa daya tarik alam terutama Bukik Batanjua, dimana bukit tersebut mempunyai keunikan yaitu di puncak bukit terdapat air jernih di dalam batu yang bersih yang dapat langsung diminum dan dapat menjadi obat bagi yang meminumnya. Pemandangan yang indah dari atas Bukik Batanjua juga menjadi daya tarik alam bagi wisatawan karena dari puncak bukit dapat terlihat pemandangan seluruh daerah Sungai Janiah hingga Jam Gadang Bukittinggi yang berjarak $\pm 25 \mathrm{Km}$.

Untuk pengembangannya, di Bukit Batanjua tersebut berpotensi dijadikan sebagai tempat camping atau tracking bagi wisatawan. Sebagaimana yang dikemukakan oleh Ketua Kelompok Sadar Wisata (Pokdarwis) Sungai Janiah dalam hasil wawancaranya:

"Kita memiliki lahan yang cukup dan dapat di buat wisata tambahan seperti tempat camping atau traking. Namun sebelumnya belum ada direncanakan karena ilmu yang dimiliki dan cara-cara untuk mengembangkannya kita masih kurang".

Namun ini masih belum dilakukan oleh pengelola karena terkendala dengan perencanaan pembangunan tangga yang belum seratus persen selesai dan juga pembuatan perencanaan tempat camping juga belum ada. Kemudian belum adanya petugas pengelola yang memantau sampai ke atas bukit batanjua akibatnya banyak ditemukan sampah yang berserakan di atas bukit tersebut.

Selanjutnya ada Kolam Ikan Sakti dengan keunikan sejarah asal mula Ikan dari manusia sudah menjadi daya tarik bagi wisatawan untuk datang ke Destinasi ini. Di 
samping itu, dengan banyaknnya debit air dari kolam tersebut bisa juga dikembangkan tempat pemandian atau tempat memancing untuk wisatawan nantinya. Di sekitar kolam ikan sakti, banyak hewan kera yang juga dapat dijadikan suatu keunikan tersendiri berwisata memberi makan kera yang lepas di alam. Selain itu karena sabagian besar penduduknya petani maka banyak terdapat hamparan sawah dan tanaman yang nanti bisa dikembangkan sebagai objek tambahan pariwisata, seperti terlihat pada Gambar 1.

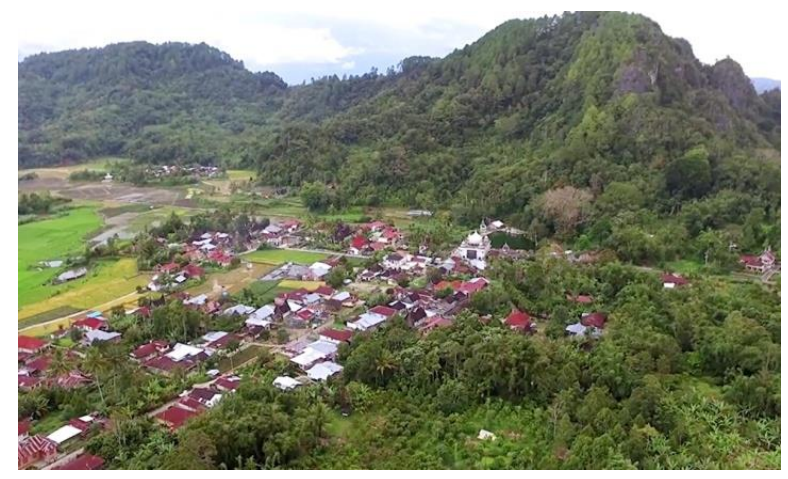

Gambar 1.

Dalam pengembangan Destinasi Pariwisata Ikan Sakti Sungai Janiah masih berjalan lambat karena susahnya pembebasan lahan untuk pariwisata, sebab sebagian besar status kepemilikan tanah adalah tanah hulayat (tanah saku atau kaum) sehingga dalam perencanaan pengembangan harus menunggu izin dan kesepakatan terlebih dahulu dari pemuka adat.

Dengan demikian daya tarik alam utama yang ada (Bukit Batanjua, Kolam Ikan, Hewan khasnya dan Sumber mata air) yang berpotensi dikembangkan dengan pembuatan tempat pemandian, tempat memancing dan pembuatan lokasi tracking dan camping di atas bukit. Berikutnya dengan memanfaatkan pohon besar di sekitar lokasi wisata dapat dikembangkan pembuatan wahana flyingfox nantinya. Hal ini dikemukakan oleh tokoh masyarakat di Sungai Janiah.

Masalah belum terkelolanya lokasi dengan baik seperti masih adanya sampah yang dibiarkan di area tersebut karena masih kurangnya petugas khusus dalam melakukan pembersihan lokasi. Untuk pengembangan dan pengelolaan dibutuhkan kerjasama antara pengelola, pemda dan masyarakat serta investor dalam mengembangkan potensi ini. Kemudian kerja sama dengan semua pihak untuk melakukan promosi sehingga dapat meningkatkan kunjungan wisatawan nantinya.

2. Daya Tarik Budaya

Daya tarik budaya yang terdapat di Sungai Janiah antara lain tradisi baralek minang, randai simalanca dan pencak silat (silek). Randai tersebut menceritakan kisah kehidupan pemuda sederhana yang rajin beribadah. Ada tiga jenis pencak silat yang berkembang di daerah ini yaitu silek kumango, silek tuo, dan silek taralak. Hal ini sesuai dengan yang dikemukakan oleh Ketua Pokdarwis Sungai Janiah bahwa.

Selanjutnya budaya yang terdapat di didestinasi wisata ini antara lain alat musik pupuik, talempoang pacik dan tradisi makan bajamba. Budaya ini merupakan daya tarik yang dimiliki masyarakat Sungai Janiah, namun pada 
saat ini daya tarik ini sudah jarang dilihat, karena masih kurangnya minat pemuda yang berdomisili di sini untuk mempelajari budaya. Apaliagi sebagian pemuda memilih merantau sehingga sangat sedikit jumlah pemuda yangsiap mengembangkan budaya di Sungai Janiah. Hal ini dikemukakan oleh kepala dinas pariwisata pemuda dan olahraga.

Jika daya tarik budaya tersebut dikembangkan dan dikemas sebagai suatu tontonan bagi wisatawan, maka diharapkan akan memberikan dampak positif bagi masyarakat Sungai Janiah. Selain bisa sebagai hiburan bagi wisatawan, juga bermanfaat bagi masyarakat sehingga dapat meningkatkan cinta terhadap budaya sendiri dan juga ekonomi masyarakat.

Untuk mewujudkan dan mengemas daya tarik budaya tersebut sangat dibutuhkan peran penting masyarakat, pengelola dan pemerintah. Sesuai dengan semboyan Nagari Kambali Ka Nagari (menghidupkan kembali budaya lama). Selain itu strategi yang dapat dilakukan adalah menanamkan dan memperkenalkan lagi budaya masyarakat ke anak-anak sejak dini. Hal ini dikemukakan oleh salah seorang tokoh masyarakat di Sungai Janiah.

Sedangkan di lain pihak, pemerintah diharapkan membantu mengembangkan daya tarik ini dengan membuat event kesenian lokal sehingga menarik minat masyarakat untuk mempelajari lebih dalam budayannya.
3. Daya Tarik Buatan

Daya tarik buatan Destinasi Pariwisata Ikan Sakti Sungai Janiah antara lain rumah adat sapasukuan dan kuburan keramat. Potensi daya tarik buatan lain yang dapat dikembangkan adalah pembuatan wahana bermain seperti memanfaatkan dua potensi alam dan buatan yang dapat dibuat flyingfox dan rumah pohon. Berikutnya juga berpeluang dikembangkan tempat memancing dan pembuatan tempat pemandian untuk wisatawan.

Meskipun begitu dalam pengembangan potensi ini sering terkendala dengan niniak mamak (Pemuka Adat) dalam izin pengembangan, karena dikhawatirkan tidak sesuai dengan budaya Sungai Janiah. Seperti yang dikemukakan oleh Kepala Dinas Pariwisata Pemuda dan Olahraga bahwa:

"Kelemahan masyarakat terkait dengan kesadaran akan pentingnya pariwisata. Pengembangan pariwisata sangat tergantung kepada izin terlebih dahulu dari niniak mamak atau pemuka adat.”.

Potensi berikutnya yaitu adanya lahan kosong yang dapat digunakan untuk pembuatan taman di sekitar destinasi ini serta penambahan pondokpondok yang mempunyai keunikan khusus nantinya. Hal ini dapat dilihat pada gambar 2. dibawah ini. 


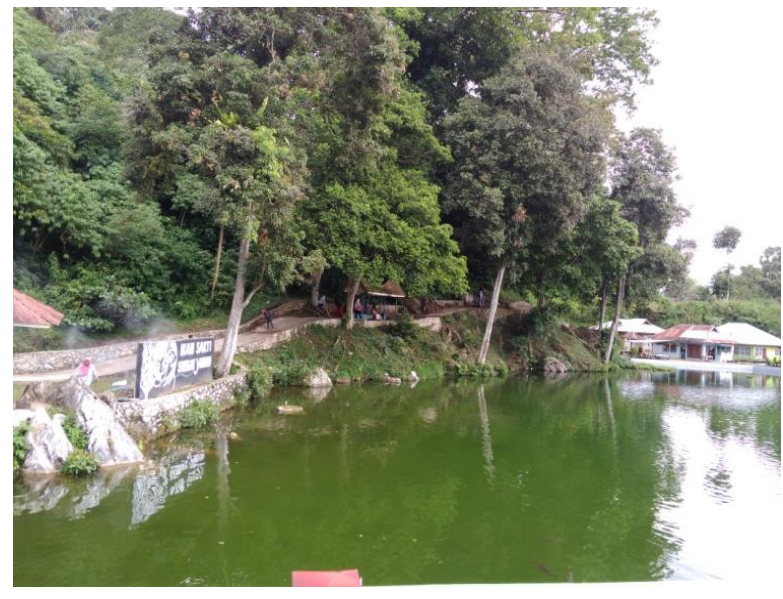

Gambar 2. Lahan Kosong untuk Daya Tarik Buatan

\section{PEMBAHASAN}

Berdasarkan hasil analisis SWOT, potensi pengembangan daya tarik wisata di Destinasi Pariwisata Ikan Sakti Sungai Janiah Kecamatan Baso Kabupaten Agam Sumatera Barat dapat dijelaskan sebagai berikut:

\section{Daya Tarik Alam (Natural Attraction)} Analisis SWOT natural attraction di Destinasi Pariwisata Ikan Sakti Sungai Janiah Kecamatan Baso Kabupaten Agam Sumatera Barat dapat dilihat pada Tabel 1 berikut ini:

Tabel 1. Analisis SWOT Natural Attraction di Destinasi Pariwisata

Ikan Sakti Sungai Janiah

\begin{tabular}{|c|c|}
\hline Kekuatan (S) & Kelemahan (W) \\
\hline $\begin{array}{l}\text { 1) Pembentukan Pokdarwis (Kelompok Sadar } \\
\text { Wisata) oleh Pemda yang beranggotakan } \\
\text { masyarakat sekitar Destinasi Pariwisata Ikan } \\
\text { Sakti Sungai Janiah. } \\
\text { 2) Daya tarik alam yang indah dan udara yang } \\
\text { masih terjaga sejuk dan bebas dari polusi } \\
\text { udara. } \\
\text { 3) Terdapatnya beberapa tempat menarik } \\
\text { lainnya yang belum dikembangkan sebagai } \\
\text { daya tarik pariwisata. } \\
\text { 4) Lokasi atau tempat yang strategis dan } \\
\text { mudah dijangkau } \pm 2,5 \mathrm{Km} \text { dari Jalan lintas } \\
\text { Sumatera. Sedangkan jarak dengan } \\
\text { Bukittinggi } \pm 23 \mathrm{Km} \text { yang merupakan salah } \\
\text { satu destinasi Unggulan di Sumatera Barat. } \\
\text { 5) Ketersedian sumber air yang banyak }\end{array}$ & $\begin{array}{l}\text { 1) Minimnya pengetahuan dan ilmu } \\
\text { masyarakat dalam pemanfaatan sumber } \\
\text { daya alam. } \\
\text { 2) Belum semua masyarakat yang memahami } \\
\text { sadar wisata } \\
\text { 3) Susahnya izin dari niniak mamak (Pemuka } \\
\text { Adat) dalam penggunaan lahan dan } \\
\text { masuknya investor dari luar untuk } \\
\text { pengembangan pariwisata. } \\
\text { 4) Pemerintah hanya pembina, pengelolaan } \\
\text { sepenuhnya dilakukan oleh masyarakat, } \\
\text { sehingga keterbatasan tenaga profesional } \\
\text { dalam mengembangkan pariwisata }\end{array}$ \\
\hline Peluang (O) & Ancaman (T) \\
\hline $\begin{array}{l}\text { 1) Jumlah kunjungan wisatawan ke Kabupaten } \\
\text { Agam cukup besar. } \\
\text { 2) Adanya kerjasama instansi pemerintah pusat } \\
\text { dan pemerintah daerah serta akademisi } \\
\text { dalam pengembangan destinasi pariwisata. } \\
\text { 3) Penetapan oleh pemda destinasi pariwisata }\end{array}$ & $\begin{array}{l}\text { 1) Berkembangnya destinasi pariwisata lain } \\
\text { yang berada disekitar destinasi pariwisata } \\
\text { ikan sakti sungai janiah dapat } \\
\text { meningkatkan persaingan } \\
\text { 2) Kerusakan pada alam yang dilakukan oleh } \\
\text { wisatawan, jika jumlah wisatawan tidak }\end{array}$ \\
\hline
\end{tabular}


Kekuatan (S)

ikan sakti sungai janiah ke dalam destinasi utama yang akan dikembangkan.

4) Masih minimnya daya tarik alam yang ada di sekitar destinasi pariwisata.
Kelemahan (W)

3) Ancaman bencana alam, karena destinasi berada pada daerah perbukitan.

Berdasarkan hasil analisis SWOT natural attraction tersebut di atas, maka dapat disusun strategi pengembangan sebagai berikut (Tabel 2).

Tabel 2. Strategi Pengembangan natural attraction di Destinasi Pariwisata Ikan Sakti Sungai Janiah

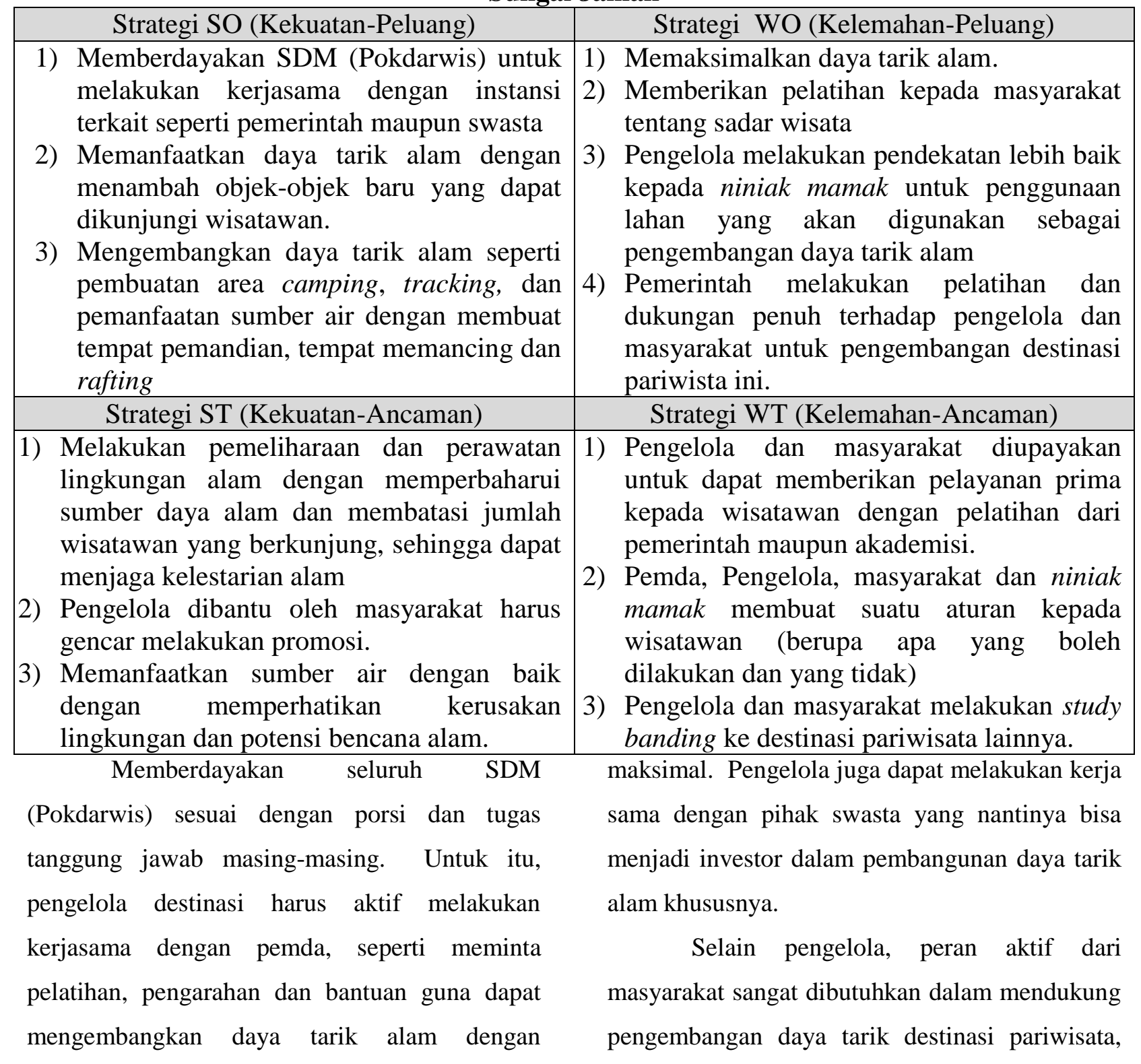


sebab masyarakat merupakan pelaku pariwisata utama. Karena, pemanfaatan daya tarik alam dapat meningkatkan ekonomi masyarakat secara langsung. Hal tersebut sejalan dengan yang dikemukakan oleh Hermantoro, (2015:2), "Pariwisata juga telah memberikan bukti bahwa sumberdaya alam dapat diolah menjadi kekuatan ekonomi yang besar tanpa merusak lingkungannya". Strategi ini dilakukan oleh pengelola dan masyarakat dengan dukugan Pemda dan Swasta.

Mengembangkan daya tarik alam seperti pembuatan area camping, tracking, dan pemanfaatan sumber air dengan membuat tempat pemandian, tempat memancing dan rafting bertujuan untuk menambah daya tampung wisatawan sehingga tidak menumpuk pada satu tempat saja. Ini dapat dilakukan oleh pengelola bersama masyarakat, niniak mamak, pemerintah daerah dan akademisi. Pihak-pihak terkait perlu melakukan promosi destinasi pariwisata misalnya dengan dengan penyebaran brosur, promosidi media sosial dan promosi secara lansung kepada calon wisatawan.

\section{Culture Attraction}

Berdasarkan analisis culture attraction di Destinasi Pariwisata Ikan Sakti Sungai Janiah di Kecamatan Baso Kabupaten Agam Sumatera Barat dapat dilihat pada Tabel 3 berikut ini:

Tabel 3. Analisis SWOT Culture Attraction di Destinasi Pariwisata Janiah

Ikan Sakti Sungai

Kekuatan (S)

1) Masyarakat menjunjung tinggi filosofi Minangkabau "Adaik basandi syarak, syarak basandi kitabullah." Masih kuatnya adat istiadat masyarakat.

2) Beraneka ragamnya adat budaya yang dimiliki oleh masyarakat.

3) Adanya masing-masing suku (Pemuka Adat) memahami adat istiadat, budaya dan kesenian Sungai Janiah

4) Adanya acara adat yang dilakukan dalam setiap bulannya
Kelemahan (W)

1) Kurangnya minat dan partisipasi pemuda

2) Sebagian besar pemuda pergi merantau dan dikampung hanya orang tua saja

3) Kurangnya ketersediaan fasilitas dan peralatan adat khusunya peralatan seni musik tradisional yang sudah langka.

4) Banyaknya aturan dan "pantangan" (larangan ) yang diasumsi oleh masyarakat.

5) Pengelola maupun pemerintah belum ada memiliki dana khusus untuk pengembangan daya tarik budaya tersebut.

6) Pemda hanya sebagai pembina dan mengarahkan dalam pengembangan

\section{Peluang $(\mathrm{O})$}

Ancaman (T)

1) Adanya rencana pemda melaksanakan event budaya di destinasi pariwisata ini.
1) Pengaruh modrenisasi dan teknologi yang dapat mempengaruhi budaya 
Kekuatan (S)

2) Belum adanya destinasi yang mengembangkan daya tarik budaya di sekitar kecamatan Baso.

1) Pemerintah mendukung pengembangan potensi budaya sebagai daya tarik wisata.

2) Adanya investor yang ingin membatu mengemas dan menjadi EO dalam pengemasan daya tarik budaya tersebut.

3) Adanya binaan dari akademisi terhadap adat budaya Sungai Janiah, sehingga dapat menjadi pedoman dalam pengembangannya.

Berdasarkan hasil analisis SWOT cultural attraction tersebut di atas, maka dapat disusun strategi pengembangan sebagai berikut (Tabel 4).

\section{Tabel 4. Strategi Pengembangan culture attraction di Destinasi Pariwisata Ikan Sakti Sungai Janiah}

\begin{tabular}{|c|c|c|}
\hline \multicolumn{2}{|r|}{ Strategi SO (Kekuatan-Peluang) } & Strategi WO (Kelemahan-Peluang) \\
\hline & $\begin{array}{l}\text { Pengelola melakukan kerjasama dengan } \\
\text { masyarakat, akademisi dan pemerintah } \\
\text { dalam pengemasan budaya serta pengadaan } \\
\text { event-event untuk memperkenalkan budaya } \\
\text { daerah sungai janiah sehingga dapat } \\
\text { menarik kunjungan wisatawan } \\
\text { Mengembangkan daya tarik budaya yang } \\
\text { ada seperti randai, silat, alat musik } \\
\text { tradisional dll, dilakukan pengemasan oleh } \\
\text { pengelola dengan masyarakat sebagai } \\
\text { pelaku utama. Dibantu pihak swasta sebagai } \\
\text { pembawa wisatawan ke destinasi pariwisata } \\
\text { tersebut }\end{array}$ & $\begin{array}{l}\text { 1) Melatih dan menanamkan budaya kepada } \\
\text { pemuda mulai dari bangku sekolah } \\
\text { sehingga dapat mempertahankan budaya } \\
\text { asli sungai janiah. } \\
\text { 2) Melakukan koordinasi dengan pemuka adat } \\
\text { tentang budaya asli sungai janiah dan } \\
\text { memetakan mana budaya (kesenian, } \\
\text { beladiri, pepatah petitih dll) yang bisa } \\
\text { dikembangkan sebagai daya tarik budaya di } \\
\text { destinasi pariwisata ikan sakti sungai janiah } \\
\text { 3) Mencarikan dana untuk membenahi dan } \\
\text { melengkapi peralatan yang dibutuhkan } \\
\text { dalam pengembangan daya tarik budaya } \\
\text { tersebut, dengan dukungan dan arahan } \\
\text { akademisi dan pemerintah }\end{array}$ \\
\hline \multicolumn{2}{|r|}{ Strategi ST (Kekuatan-Ancaman) } & Strategi WT (Kelemahan-Ancaman) \\
\hline & $\begin{array}{l}\text { Tokoh masyarakat (Pemuka adat) dan } \\
\text { pengelola bekerjasama membuat aturan } \\
\text { didestinasi pariwisata yang kemudian } \\
\text { dipublikasikan kepada wisatawan. }\end{array}$ & $\begin{array}{l}\text { 1) Memberdayakan pemuda daerah sebagai } \\
\text { penggerak kepariwisataan daerah dengan } \\
\text { memberikan pelatihan dan pemahaman } \\
\text { terhadap pariwisata }\end{array}$ \\
\hline & $\begin{array}{l}\text { Mengikuti perkembangan teknologi dengan } \\
\text { mengoptimalkan atau memanfaatkannya }\end{array}$ & $\begin{array}{l}\text { 2) Mengidentifikasi pantangan (larangan) } \\
\text { yang diasumsi masyarakat sebagai suatu }\end{array}$ \\
\hline
\end{tabular}




\begin{tabular}{|l|l|}
\hline Strategi SO (Kekuatan-Peluang) & \multicolumn{1}{|c|}{ Strategi WO (Kelemahan-Peluang) } \\
\hline $\begin{array}{l}\text { sebagai sarana promosi dengan tetap } \\
\text { menjaga budaya asli daerah. }\end{array}$ & $\begin{array}{l}\text { keunikan daerah } \\
\text { 3) Meningkatkan fasilitas pendukung } \\
\text { terselenggaranya event budaya sebagai } \\
\text { daya tarik bagi wisatawan }\end{array}$ \\
\hline
\end{tabular}

Berdasarkan Tabel 4 di atas dapat dilihat bahwa strategi untuk mengembangan culture attraction di Destinasi Pariwisata Ikan Sakti Sungai Janiah Kecamatan Baso Kabupaten Agam dapat dilakukan dengan beberapa cara.

Pengelola melakukan kerjasama dengan masyarakat, akademisi dan pemerintah dalam pengemasan budaya seperti adat istiadat serta keunikan dari masyarakat yang kemudian dijadikan sebagai suatu daya tarik. Kemudian pembuatan dan pengadaan event-event budaya yang bertujuan untuk memperkenalkan budaya daerah sungai janiah sehingga dapat menarik kunjungan wisatawan.

Daya tarik budaya yang dapat dikembangkan seperti randai, silat, alat musik tradisional dan tradisi adat masyarakat seperti makan bajamba. Semua ini dikemas menjadi culture attraction yang menarik wisatawan.

Tokoh masyarakat (Pemuka adat) dan pengelola bekerjasama membuat aturan di destinasi pariwisata yang kemudian dipublikasikan kepada wisatawan. Ini dapat dilakukan dengan memajang aturan berkunjung di dekat pintu gerbang memasuki destinasi pariwisata serta publikasi melalui internet sehingga wisatawan dapat memahami daerah tersebut sebelum melakukan perjalanan wisata dan dapat menjaga keaslian budaya masyarakat sekitar.

\section{Mengikuti perkembangan teknologi} dengan mengoptimalkan atau memanfaatkannya sebagai sarana promosi dengan tetap menjaga budaya asli daerah. Hal tersebut dapat dilakukan dengan memberdayakan seluruh teknologi yang digunakan oleh masyarakat, seperti teknologi komunikasi (android), masyarakat dapat membantu promosi budaya asli melalui internet, sehingga budaya yang dimiliki lebih dikenal lagi.

Sedikitnya pemuda yang memahami budaya atau adat istiadat maka dapat dilakukan pelatihan serta menanamkan konsep budaya kepada pemuda mulai dari bangku sekolah sehingga dapat mempertahankan budaya asli sungai janiah. Jika tidak dilakukan maka budaya asli di destinasi pariwisata ikan sakti sungai janiah dapat hilang.

Strategi ini dapat dilakukan oleh pengelola dengan bantuan pemuka adat. Selain itu juga meningkatkan fasilitas pendukung terselenggaranya event budaya sebagai daya tarik bagi wisatawan seperti pembuatan panggung kesenian, dan melengkapi peralatan yang dibutuhkan. Hal ini dapat dilakukan oleh pengelola dengan bantuan pemda. 


\section{Man Made Attraction}

Berdasarkan analisis SWOT man made

attraction di Destinasi Pariwisata Ikan Sakti

Sungai Janiah Kecamatan Baso Kabupaten Agam
Sumatera Barat dapat dilihat padaTabel 5 berikut ini

Tabel 5. Analisis SWOT Man Made Attraction di Destinasi Pariwisata Ikan Sakti Sungai Janiah

\section{Kekuatan (S)}

\section{Kelemahan (W)}

1) Adanya lahan kosong yang luas untuk pembuatan man made attraction didestinasi pariwisata ikan sakti sungai janiah

2) Masih kurangnya daya tarik buatan disekitar destinasi pariwisata ikan sakti sungai janiah
1) Ilmu yang dimiliki masyarakat dalam mengembangkan potensi masih kurang.

2) Pemuka adat sulit mengeluarkan izin penggunaan lahan.

3) Ide kreatif pengelola dan masyarakat belum berkembang.

Peluang (O)

Ancaman (T)

1) Adanya dukungan pemda terhadap pengembangan daya tarik buatan.

2) Adanya investor bagi pengembangan daya tarik buatan di destinasi wisata ini.

3) Masih kurangnya daya tarik buatan disekitar destinasi pariwisata ikan sakti sungai janiah

4) Pemerintah akan memberikan bantuan dana berdasarkan proposal yang dibuat oleh pengelola destinasi pariwisata

5) Adanya kerjasama dengan akademisi dalam pengembangan daya tarik ini

Setelah diketahui kekuatan, kelemahan, peluang dan ancaman man made attraction di Destinasi Pariwisata Ikan Sakti Sungai Janiah di Kecamatan Baso Kabupaten
1) Persaingan dengan destinasi pariwisata lain yang sudah duluan mengembangkan daya tarik buatan di Sumatera Barat.

2) Pengaruh dari wisatawan, tidak sesuainya perilaku wisatawan dengan budaya masyarakat lokal.

3) Kurangnya dana dalam melakukan pembangunan daya tarik buatan.

4) Adanya peraturan yang menyatakan bahwa Pemda tidak bisa membangun secara fisik di destinasi yang tidak dikelola oleh Pemda

Agam Sumatera Barat, maka strategi pengembangan dapat dilihat pada Tabel 6 berikut:

Tabel 6. Strategi Pengembangan Man Made Attraction di Destinasi Pariwisata Ikan Sakti Sungai Janiah

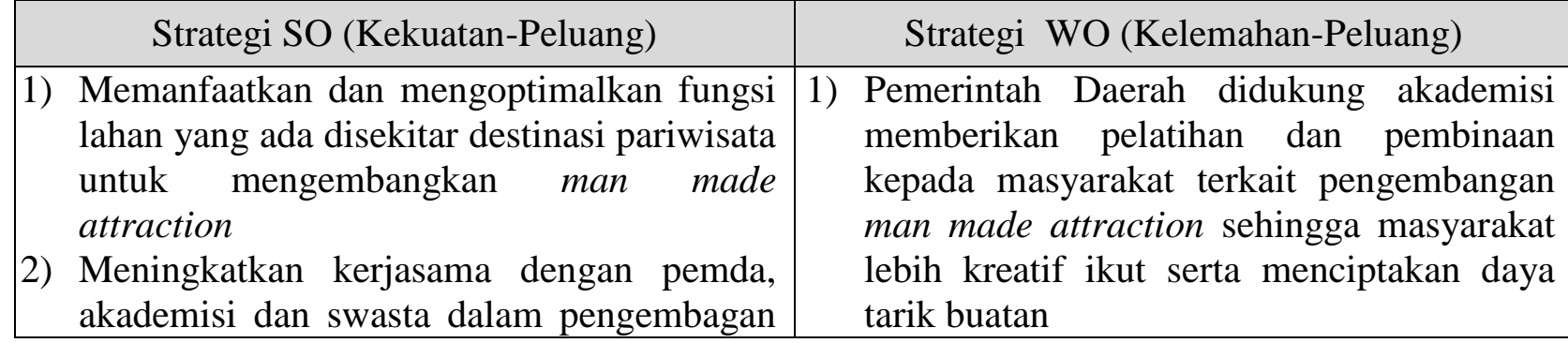


man made attraction serta membuka peluang kepada investor untuk pembangunan destinasi

2) Pengelolaan destinasi pariwisata tersebut sebaiknya melibatkan masing-masing pemuka adat dalam pengurus pengelola destinasi pariwisata

\section{Strategi ST (Kekuatan-Ancaman)}

1) Menciptakan man made attraction dengan memanfaatkan lahan sekitar destinasi sesuai dengan kehidupan sosial masyarakat untuk menciptakan ciri khas destinasi pariwisata tersendiri

2) Melakukan study banding ke destinasi pariwisata yang sudah maju dalam pengelolaan daya tarik buatan serta menjadikannya sebagai mitra pariwisata

Berdasarkan Tabel 6 di atas dapat dijelaskan bahwa strategi untuk mengembangan man made attraction di Destinasi Pariwisata Ikan Sakti Sungai Janiah Kecamatan Baso Kabupaten Agam dapat dilakukan dengan beberapa cara yaitu dengan memanfaatkan dan mengoptimalkan fungsi lahan yang ada disekitar destinasi pariwisata untuk mengembangkan man made attraction seperti pembuatan flyingfox, pondok-pondok, rumah pohon, tempat bermain dan lainnya. Penggunaan lahan tersebut dapat dilakukan dengan dukungan dari masyarakat dan tokoh masyarakat sekitar. Karena sebagian besar tanah di sekitar destinasi adalah tanah pusaka. Dengan penambahan dan pengembangan daya tarik buatan tersebut dapat meningkatkan kunjungan wisatawan.

Pengelola meningkatkan kerjasama dengan pemda, akademisi dan swasta dalam pengembagan man made attraction serta membuka peluang kepada investor untuk pembangunan destinasi. Pemda merupakan pendorong dalam pengembangan daya tarik buatan tersebut seperti membantu memberikan perencanaan pembangunan dan juga pelatihan kepada pengelola nantinya. Akademisi mempunyai peran penting dalam peningkatan sdm terkait, seperti pengelola maupun masyarakat sebagai pelaku wisata nantinya. Sedangkan untuk peningkatan pembangunan daya tarik buatan dibutuhkan investor yang mampu melaksanakan pembangunan. Dengan demikian kerjasama dengan stakeholder yang ada dapat meningkatkan kunjungan wisatawan dan menaikan ekonomi masyarakat.

Menciptakan daya tarik buatan dengan memanfaatkan lahan sekitar destinasi sesuai dengan kehidupan sosial masyarakat untuk menciptakan keunikan destinasi pariwisata ikan sakti sungai janiah. Ini dilakukan oleh pengelola dengan dukungan pemda membangun daya tarik buatan tersebut dengan nuansa khas minang. 
Kemudian menjadikan daya tarik buatan tersebut bisa dinikmati oleh semua jenis wisatawan.

Melakukan study banding ke destinasi pariwisata yang sudah maju dalam pengelolaan daya tarik buatan serta menjadikannya sebagai mitra pariwisata. Pengelola dan masyarakat bersinergi untuk menciptakan daya tarik buatan serta memberikan pelayanan prima dalam pengelolaannya. Hal tersebut dapat dilakukan dengan melihat destinasi yang sudah berkembang sebagai acuan dan pedoman terhadap keinginan wisatawan.

Pemerintah Daerah didukung akademisi memberikan pelatihan dan pembinaan kepada masyarakat terkait pengembangan man made attraction sehingga masyarakat lebih kreatif ikut serta menciptakan daya tarik buatan. Strategi ini dapat dilakukan lebih detail oleh pemda terutama dalam pembenahan fisik daya tarik buatan tersebut sedangkan akademisi membantu memberikan pelatihan sdm dalam pengelolaan daya tarik buatan tersebut.

Pengelola dalam menciptakan daya tarik buatan melibatkan masing-masing pemuka adat sebagai tim pengelola yang masuk di organisasi destinasi pariwisata. Ini bertujuan untuk mempercepat pembangunan dan pengembangan daya tarik buatan, karena didaerah tersebut setiap pembangunan yang dilakukan harus disetujui oleh pemuka adat terlebih dahulu. Selain itu pemuka adat diikut sertakan dalam pembuatan pertaturan bagi pelaku wisata maupun wisatawan.

\section{SIMPULAN DAN SARAN}

1. Simpulan

Potensi pengembangan daya tarik wisata di Destinasi Pariwisata Ikan Sakti Sungai Janiah dapat dilihat dari aspek kekuatan, kelemahan, peluang dan ancaman. Keberadaan kelompok Sadar Wisata yang telah dikukuhkan oleh Dinas Pariwisata pada tahun awal 2017, loksi yang mudah dijangkau, alami dan sejuk, ketersediaan lahan kosong, adanya tatatan hidup sosial yang konstruktif dan keunikan adat dan budaya merupakan kekuatan yang harus dijadikan modal utama dalam pengembangan Destinasi Pariwisata Ikan Sakti Sungai Janiah. Sinergi diantara para pihak terkait perlu ditingkatkan untuk mengatasi kelemahan yang berupa kesulitan investor dalam mendapatkan izin dari ninik mamak dan pemuka adat, kurangnya ilmu pengetahuan, pemahaman sadar wisata masyarakat, ketersediaan tenaga professional dan partisipasi pemuda, serta terbatasnya wewenang pemerintah.

Sementara itu, peluang yang dapat dimanfaatkan dalam pengembangan Destinasi Pariwisata Ikan Sakti Sungai Janiah adalah sudah adanya kerjasama instansi pemerintah pusat dan pemerintah daerah, dalam kerjasama dengan akademisi, tingkat persaingan antar destinasi wisata yang masih rendah, meningkatya kunjungan wisata, adanya kebijakan Pemda yang menetapkan destinasi pariwisata Ikan Sakti Sungai Janiah merupakan salah satu destinasi utama yang akan dikembangkan di Kabupaten 
Agam serta adanya investor yang berminat untuk berinvestasi di sini.

Adapun ancaman yang perlu diwaspadai dan diatasi adalah dapak negatif budaya asing terhadap budaya lokal, kemungkinan hadirnya kompetitor destinasi wisata dari daerah tetangga, penurunan kualitas lingkungan dan bencana alam akibat pemanfaatan sumberdaya alam yang tidak seimbang.

\section{Saran}

Diharapkan Dinas Pariwisata Pemuda dan Olahraga Kabupaten Agam meningkatkan pembinaan yang berkelanjutan antara lain melalui program pelatihan kepada pengelola dan masyarakat setempat. Sangat diharapkan agar Pemda lebih gencar lagi melakukan promosi dengan menonjolkan daya tarik wisata dengan mengadakan event-event yang nantinya dapat dipublikasi dimedia sosial. Sehingga dapat meningkat kunjungan wisatawan yang dapat berdampak positif terhadap ekonomi masyarakat.

Kepada Pengelola Destinasi Pariwisata

diharapkan agar dapat melihat potensi daya tarik wisata dengan merealisasikan strategi pengembangan daya tarik alam, daya tarik budaya dan daya tarik buatan di Destinasi Pariwisata Ikan Sakti Sungai Janiah. Berperan aktif menjalin kerjasama dengan dengan berbagai pihak seperti pemerintah sebagai pengarah dan mendukung kemajuan pariwisata, akademisi dalam melakukan research didestinasi pariwisata tersebut sehingga mendapat masukan dan saran dalam mengembangkannya, mencari investor yang dapat mendukung dalam pengembangan secara fisik.

Diharapkan ada penelitian lanjutan daya tarik wisata di Destinasi Pariwisata Ikan Sakti Sungai Janiah bagi pengembangan daya tarik alam, budaya dan buatan manusia, sehingga menjadi masukan dan bahan untuk kemajuan destinasi pariwisata tersebut.

\section{DAFTAR PUSTAKA}

Hermantoro, Henky, 2015. Kepariwisataan Destinasi Pariwisata Produk Wisata. Depok: Aditri.

Kelly, Ian dan Tony Nankervis, 2001. Visitor Destinations. Sydney: Calaloguins

Rangkuti, Fredy. 2000. Analisis SWOT Teknik Membedah Kasus Bisnis. Jakarta: Gramedia Pustaka Utama.

2011. SWOT Balanced Scorecard. Jakarta: PT. Gramedia Pustaka Utama

.Rencana Induk Pembangunan Kepariwisataan Kabupaten Agam, 2016

Suchaina. 2014. Pengaruh Kualitas Fasilitas Sarana Dan Prasarana Terhadap Peningkatan Jumlah Pengunjung Wisata Danau Ranu Grati. Jurnal Psikologi. Pasuruan.

2011. Metode Penelitian Kombinasi (Mixed Methods). Yogyakarta: Alfabeta.

Undang-undang Republik Indonesia No.10 tahun 2009 tentang Kepariwisataan. 